\title{
Sites in Northern Louisiana with Major Collections of Historic Caddo and Other Native American Pottery
}

Jeffery S. Girard

Northwestern State University of Louisiana

Follow this and additional works at: https://scholarworks.sfasu.edu/ita

Part of the American Material Culture Commons, Archaeological Anthropology Commons, Environmental Studies Commons, Other American Studies Commons, Other Arts and Humanities Commons, Other History of Art, Architecture, and Archaeology Commons, and the United States History Commons

Tell us how this article helped you.

This Article is brought to you for free and open access by the Center for Regional Heritage Research at SFA ScholarWorks. It has been accepted for inclusion in Index of Texas Archaeology: Open Access Gray Literature from the Lone Star State by an authorized editor of SFA ScholarWorks. For more information, please contact cdsscholarworks@sfasu.edu. 


\section{Sites in Northern Louisiana with Major Collections of Historic Caddo and Other Native American Pottery \\ Creative Commons License \\ (c) (1) (9)}

This work is licensed under a Creative Commons Attribution-NonCommercial 4.0 International License 


\title{
SITES IN NORTHERN LOUISIANA WITH MAJOR COLLECTIONS OF HISTORIC CADDO AND OTHER NATIVE AMERICAN POTTERY
}

\author{
Jeffrey S. Girard
}

Archaeological sites in northern Louisiana that date to the $18^{\text {th }}$ and $19^{\text {th }}$ centuries which have yielded significant amounts of Native American pottery are plotted on the accompanying map (Figure 1), and briefly summarized below. A common feature of ceramic collections from these sites is the prevalence of shell temper, a trait that is rare prior to the late $17^{\text {th }}$ century in the region. The earliest contexts (McLelland, Joe Clark, Beene Plantation, and Henry Mound) probably date from the late $17^{\text {th }}$ to the carly $18^{\text {th }}$ centuries and include utilitarian types (such as Karnack Incised and Belcher Ridged) that were common during the Late Caddo period (ca. A.D. 1500-1700). By the middle $18^{\text {th }}$ century, these types apparently were no longer used as shown by their absence at Los Adaes and sites along Cane River. Many traditional Caddo vessel forms (such as bottles and carinated bowls) appear to have dropped out of use during the late $18^{\text {th }}$ century. Several early $19^{\text {th }}$ century sites that relate to occupants of the ethnically-mixed Bayou Pierre community north of Natchitoches contain Native American shell-tempered pottery, but represented vessel forms are similar to the "Colonoware" that is widespread in the eastern U.S. A small number of engraved and incised sherds have been recovered at these sites, but it is possible that they are from earlier Caddo occupations. Groups that originated east of the Mississippi Valley moved into northern Louisiana during the late $18^{\text {th }}$ century, and new types such as Zimmerman Black, Chickashae Red, Chickashae Combed, and Chattahoochee Roughened appear in the archaeological record. Native American pottery disappears from the archaeological record in the region by 1830 .

\section{Natchitoches area}

Most of the Caddo historic pottery from the Natchitoches area was recovered in early $18^{\text {th }}$ century graves along Cane River at the Fish Hatchery (16NA9) (Walker 1935), Southern Compress (16NA14) (Gregory and Webb 1965), Lawton Gin (16NA13) (Webb 1945), and Parkway (16NA589) (Girard 2002) sites (also see Webb and Gregory 1986). Vessels, or portions of vessels, of undecorated, Natchitoches Engraved, Keno Trailed, Emory Punctated Incised, and Fatherland or Cracker Road Incised have been recovered. Shell-tempered sherds, including several examples of Natchitoches Engraved, have been found at possible early $18^{\text {th }}$ century Natchitoches habitation areas at the American Cemetery (16NA67) (Morgan 2005) and Lambre Point sites (Girard 1997). French habitation at the Whittington (16NA241) site (David Morgan, personal communication 2006) and Oakland Plantation (16NA295) (Miller and Wood 2000) have yielded similar sherds. The cemeteries probably date to the early $18^{\text {th }}$ century. Sherds from the habitation areas may range as late as the early $19^{\text {th }}$ century. Collections are housed at Northwestern State, University and the Smithsonian Institution. 


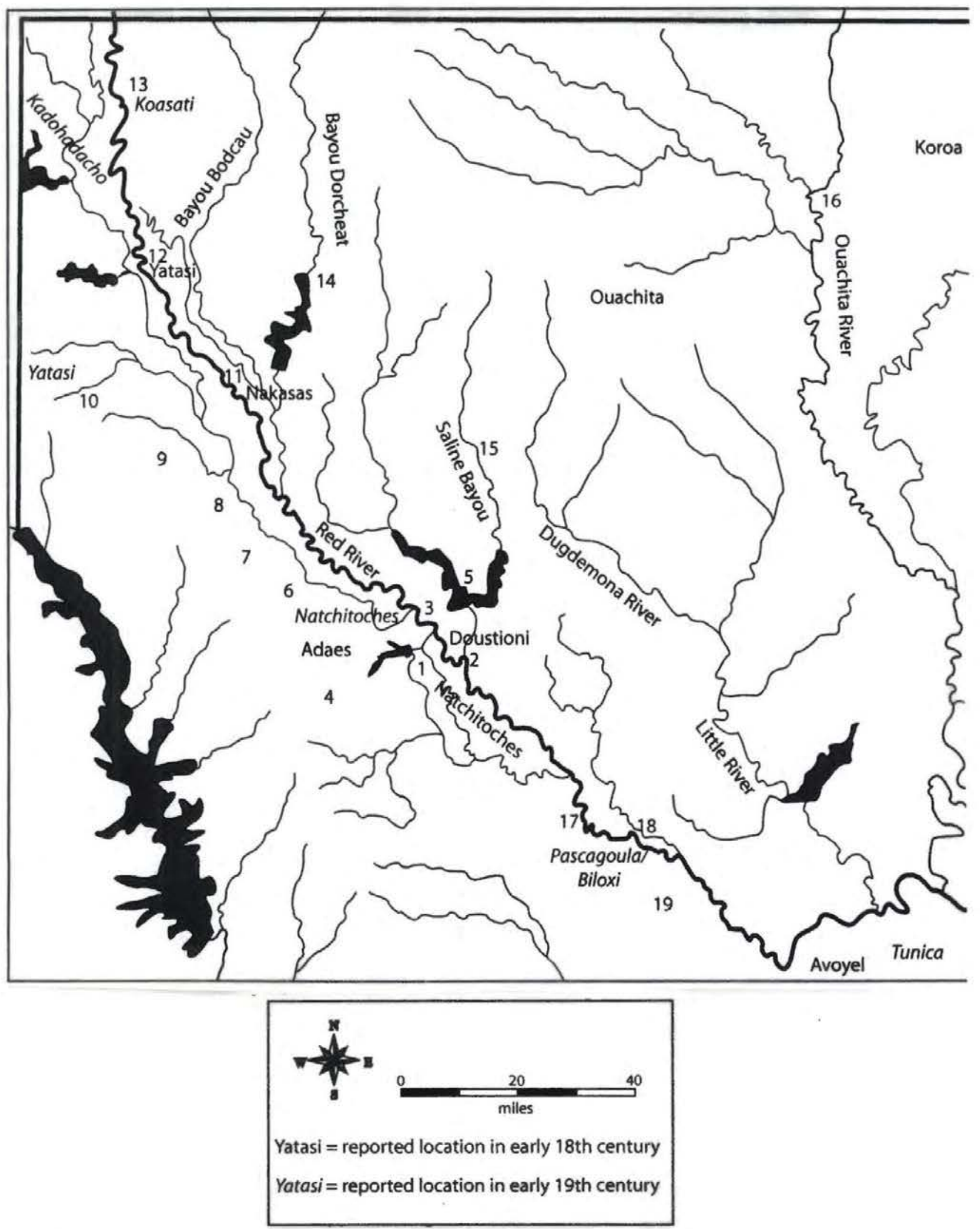

Figure 1. Map of $18^{\text {th }}$ and early $19^{\text {th }}$ century Native American sites in northern Louisiana discussed in the text. 


\section{St. Maurice Site (16WN265)}

The St. Maurice Site is a possible early $18^{\text {th }}$ century Natchitoches or Doustioni settlement mixed with later $19^{\text {th }}$ century artifacts. Shell-tempered sherds, including probable Natchitoches Engraved specimens, were found on an eroding slope at the site (Girard 1997). The collection is housed at Northwestern State University.

\section{Henry or Campti Mound}

A mound that slumped into the Red River during the late $19^{\text {th }}$ century was reported by Beyer (1897). Examples of Natchitoches Engraved, Keno Trailed, Belcher Ridged or Karnack Brushed Incised, and Fatherland or Cracker Road Incised vessels or large sherds are illustrated by drawings in Beyer's report. The vessels suggest that the mound dated to the late $17^{\text {th }}$ or early $18^{\text {th }}$ century, and might be one of the last constructed by the Caddos. Unfortunately, neither the current location of the specimens nor the location of the site is known.

\section{Los Adaes (I6NA16)}

Los Adaes is the Spanish presidio and mission that served as the first capital of Texas. Large amounts of shell-tempered Caddo pottery have been recovered from the site. Although most vessels appear to have been undecorated, examples of Natchitoches Engraved, Emory Punctated Incised, Ebarb Incised, Patton Engraved, Womack Engraved, Chickashae Combed, and Fatherland Incised also are present (Gregory 1973; Gregory et al. 2004; Avery 1996, 1997; see also Gregory and Avery, this volume). Collections are housed at Northwestern State University.

\section{Fredericks II (I6NA21)}

Fredericks II is a small late Woodland period mound situated on the bank of Black Lake Bayou (Girard 2002). A small number of shell-tempered Caddo sherds was recovered from the top of the mound during test excavations conducted by Donald Hunter and students at Northwestern State University in the 1970s. Types represented in the collections at Northwestern State University include Natchitoches Engraved, Belcher Ridged, and Foster Trailed Incised.

\section{The Wilkinson (IGA3), Allen (IGNA4), and Rocks Bayou (16NA1) sites}

Collections made by James Ford from these three sites mostly contain Early to Middle Caddo period sherds. However, some historic types are present as well, and burials from the Allen and Wilkinson sites included glass trade beads. One Natchitoches Engraved bowl reportedly came from the Wilkinson site (Ford 1936; Kelley 1998). The materials recovered by Ford are housed at Louisiana State University in Baton Rouge. Sherd collections made by Webb and Gregory are present at Northwestern State University. 


\section{Dolet Bayou No. 1 (16DS274)}

A site that relates to the late $18^{\text {th }}$ century homeplace of Pierre Dolet is located in southern DeSoto Parish on the western margin of the Red River floodplain. Treasure hunters excavated possible historic Caddo burials with intact vessels suggesting that the site was occupied by the Yatasis or Adaes during the middle $18^{\text {th }}$ century. A surface collection containing faience, creamware, pearlware, and undecorated shell-tempered pottery is housed at Northwestern State University (Girard 1992).

\section{The Smithport Landing (16DS4), Louis Procello (16DS212), and Vital Flores (16DS389) sites}

These sites are clustered in the Smithport/Clear Lake area on the western side of the Red River floodplain. Smithport Landing is primarily a prehistoric site that also includes shell-tempered curvilinear incised, and engraved sherds likely to relate to an occupation of the middle $18^{\text {th }}$ century Yatasi (Webb 1963). The Procello (Espey Huston and Associates 1983) and Flores (Girard 2003) sites are early $19^{\text {th }}$ century occupations of members of the Bayou Pierre community. A prehistoric occupation, including human burials, also is represented at the Procello site. These sites contain creamware and pearlware, along with primarily undecorated shell-tempered pottery. Materials from all three sites are housed at Northwestern State University.

\section{Robleau sites (16DS380-385)}

A cluster of sites overlooking Bayou Nabonchasse relates to the early $19^{\text {th }}$ century homestead of Pierre Robleau (Girard 2002; Girard et al. 2006). Creamware, pearlware, and large amounts of shell-tempered pottery are present in collections at Northwestern State University. A few sherds with engraved hatched zones and ticked lines are included in the collections, as well as small amounts of Chickashae Red and Chickashae Combed. The Robleau family was heavily involved in trade with the Yatasis and other Native American groups during the early $19^{\text {th }}$ century.

\section{Keatchie Site (16DS1)}

This extensive site contains unusual shell and bone tempered ceramics that probably date to the late $18^{\text {th }}$ or early $19^{\text {th }}$ century. A late Yatasi occupation might be represented. A surface collection obtained by Clarence Webb is housed at Northwestern State University (Webb, n.d.).

\section{McLelland and Joe Clark sites (16CD236, 237, and 244)}

Late $17^{\text {th }}$ to early $18^{\text {th }}$ century occupations probably relating to the Nakasas (or Natachez) group as identified by Tonti in 1690 and Bienville in 1700 are represented at these sites (Kelley 1994, 1997; Kelley et al. 1996). McLelland is the most thoroughly investigated protohistoric to historic site in Northwest Louisiana. Collections are housed 
at Coastal Environments, Inc. in Baton Rouge. Small surface collections from McLelland and Joe Clark No. 2 are at Northwestern State University.

\section{Beene Plantation (16BO19)}

A collection of sherds obtained by Clarence Webb and Robert Fulton includes Natchitoches Engraved, Emory Punctated Incised or Foster Trailed Incised, Belcher Ridged, and Karnack Brushed Incised (Girard 2006). Two Keno Trailed vessels housed at the American Museum of Natural History in New York probably came from the site (Gonzalez et al. 2005). The site may be part of a dispersed Yatasi village reported by Tonti in 1690 and Bienville in 1700.

\section{Coushatta Bluffs (16B0172-175; 16BO185-187; 16BO205-207)}

These sites are the remains of an early $19^{\text {th }}$ century Koasati village on a bluff overlooking the Red River floodplain in Bossier Parish. The Koasatis reportedly occupied the site of an abandoned Caddo village. Collections are housed at Southern Arkansas University and include large numbers of mostly undecorated non-tempered and shell-tempered sherds and one complete vessel (McCrocklin 1990; Jurney and Perttula 1995).

\section{Potter's Pond (16WE76)}

Potter's Pond is a salt lick on the north side of Lake Bistineau. Large numbers of, mostly undecorated, shell-tempered sherds have been recovered on the east side of the pond. Limited test excavations resulted in the recovery of several undecorated bowls, a complete Foster Trailed Incised jar, and a partial Fatherland or Cracker Road Incised vessel. Collections acquired by the Louisiana Archaeological Society are housed at Southem Arkansas University. Additional sherds are in the collections at Northwestern State University. The occupation probably dates to late $17^{\text {th }}$ or early $18^{\text {th }}$ century (McCrocklin 1985; Girard 2006).

\section{Drakes Lick (I6NA11).}

This is another extensive salt lick with numerous shell-tempered sherds. No systematic investigations have been conducted at the site, but surface collections are housed at Northwestern State University.

\section{Glendora (16OU18) and Keno (16MO31) sites}

Glendora and Keno are protohistoric cemeteries excavated by C. B. Moore. The vast collections of complete vessels reported by Moore include the types Foster Trailed Incised, Keno Trailed, and Natchitoches Engraved. The site might be affiliated with the historic Koroa (Moore 1909; Kidder 1990; Weinstein et al. 2003). 


\section{Colfax Landing (16NA15 - actually in Rapides Parish)}

This is a late $18^{\text {th }}$ to early $19^{\text {th }}$ century Pascagoula-Biloxi cemetery located on a bluff overlooking the Red River floodplain. Most of the material culture is of European origin, but some shell-tempered ceramics are included. Collections are housed at Louisiana State Exhibit Museum in Shreveport and Northwestern State University).

\section{Zimmerman Hill (16RA335)}

Zimmerman Hill is a late $18^{\text {th }}$ to early $19^{\text {th }}$ century Apalachee village located on a hill at the edge of the Red River floodplain. Abundant non-tempered and shell tempered sherds were recovered during test excavations in 1985 and 1986. Represented types include Bell Plain, Mississippi Plain, Fatherland Incised, Maddox Engraved, Old Town Red, and Zimmerman Black. Collections are housed at Coastal Environments, Inc. in Baton Rouge (Hunter 1990).

\section{Bayou Bouef (16RA60, 16RA104, 16RA950)}

These three sites relate to late $18^{\text {th }}$ to early $19^{\text {th }}$ century villages of the Biloxi, Pascagoula, Chato, Yowani, and Choctaw along the western margin of Bayou Boeuf in Rapides Parish. Shell-tempered sherds are present from surface collections and limited test excavations. Collections are present at Coastal Environments, Inc. in Baton Rouge (Heartfield et al. 1978; Hunter 1994; Girard 1999).

\section{References Cited}

Avery, George

1996 Eighteenth Century Spanish, French, and Caddoan Interactions as seen from Los Adaes. Journal of Northeast Texas Archaeology 7:27-68.

1997 More Friend Than Foe: Eighteenth Century Spanish, French, and Caddoan Interaction at Los Adaes; A Capital of Texas Located in Northwestern Louisiana. Louisiana Archaeology 22:163-193.

Beyer, George E.

1897 The Mounds of Louisiana. Publications of the Louisiana Historical Society 2(1):7-27. New Orleans.

Espey, Huston \& Associates, Inc.

1983 The Archaeological Investigation of the Louis Procello Site, 16DS212, DeSoto Parish, Louisiana. Report to Southwestern Electric Power Company by Espey, Huston and Associates, Austin. 
Ford, James A.

1936 Analysis of Indian Village Site Collections from Louisiana and Mississippi. Louisiana Geological Survey Anthropological Study No. 2.

Girard, Jeffrey S.

1992 Regional Archaeology Program, Management Unit 1: Third Annual Report. Report on file at the Louisiana Division of Archaeology, Department of Culture, Recreation, and Tourism, Baton Rouge.

1997 Historic Caddoan Occupation in the Natchitoches Area: Recent Attempts to Locate Residential Sites. Caddoan Archeology 8(3): 19-31.

1999 Regional Archaeology Program, Management Unit 1: Tenth Annual Report. Report on file at the Louisiana Division of Archaeology, Department of Culture, Recreation, and Tourism, Baton Rouge.

2002 Regional Archaeology Program, Management Unil 1: Thirteenth Annual Report. Report on file at the Louisiana Division of Archaeology, Department of Culture, Recreation, and Tourism, Baton Rouge.

2003 Regional Archaeology Program, Management Unit 1: Fourteenth Annual Report. Report on file at the Louisiana Division of Archaeology, Department of Culture, Recreation, and Tourism, Baton Rouge.

2006 Regional Archaeology Program, Management Unit 1: Seventeenth Annual Report. Report on file at the Louisiana Division of Archaeology, Department of Culture, Recreation, and Tourism, Baton Rouge.

Gonzalez, Bobby, Robert Cast, Timothy K. Perttula, and Bo Nelson

2005 A Rediscovering of Caddo Heritage, The W.T. Scoll Collection at the American Museum of Natural History and Other Caddo Collections from Arkansas and Louisiana. Caddo Nation of Oklahoma, Historic Preservation Program, Binger, Oklahoma.

Gregory, Hiram F.

1973 Eighteenth Century Caddoan Archaeology: A Study in Models and Interpretation. Ph.D. dissertation, Department of Anthropology, Southern Methodist University, Dallas.

Gregory, Hiram F. and Clarence H. Webb

1965 European Trade Beads from Six Sites in Natchitoches Parish, Louisiana. Florida Anthropologist 18(3):15-44.

Gregory, Hiram F., George Avery, Aubra L. Lee, and Jay C. Blaine

2004 Presidio Los Adaes: Spanish, French, and Caddoan Interaction on the Northern Frontier. Historical Archaeology 38(3):65-77. 
Heartfield, L., K. Hudson, G .R. D. Price, S. Mitcham, H. E. Jackson, and G. S. Greene

1978 A Cultural Resource Survey and Evaluation of the Opelousas to Shrevepon Portion of the Proposed North-Soputh Expressway, Phases I and II. Heartfield, Price, and Greene, Inc., Monroe.

Hunter, Donald

1990 The Apalachee on Red River, 1763-1834: An Ethnohistory and Summary of Archaeological Testing at the Zimmerman Hill Site, Rapides Parish, Louisiana. Louisiana Archaeology 12:7-127.

1994 The Biloxi on Bayou Boeuf: An Ethnohistory and Analysis of Surface Collections from the Biloxi Village Site (16-Ra-60), Rapides Parish, Louisiana. Mississippi Archaeology 29(2):18-43.

Jurney, David H. and Timothy K. Perttula

1995 Nineteenth-Century Alibamu-Koasati Pottery Assemblages and Culinary Traditions. Southeastern Archaeology 14(1): 17-30.

Kelley, David B.

1994 The McLelland and Joe Clark Siles: Protohistoric-Historic Caddoan Farmsteads in Southern Bossier Parish, Louisiana. Report submitted to the U.S. Army Corps of Engineers, Vicksburg District. Coastal Environments Inc., Baton Rouge.

1997 Two Caddoan Farmsteads in the Red River Valley. Research Series No. 51. Arkansas Archeological Survey, Fayetteville.

1998 Protohistoric and Historic Caddoan Occupation of the Red River Valley in Northwest Louisiana. In The Native History of the Caddo, Their Place in Southeastern Archeology and Ethnohistory, edited by T. K. Perttula and J. E. Bruseth, pp. 91-112. Studies in Archeology 30. Texas Archeological Research Laboratory, The University of Texas at Austin.

Kelley, David B., D.G. Hunter, E.S. Gardner, D.C. Weinand, A. Tine, and L.L. Tieszen

1996 The McLelland and Joe Clark Sites: Protohistoric-Historic Caddo Farmsteads in the Red River Valley of Northwest Louisiana. Southeastern Archaeology 15(1):81-102.

Kidder, Tristram R.

1990 The Ouachita Indians of Louisiana: An Ethnogistorical and Archaeological Investigation. Louisiana Archaeology 12:179-201.

McCrocklin, Claude

1985 Potter's Pond, 16WE76, A Caddo Salt and Pottery-Making Site. Arkansas Archaeological Society Field Notes 202:3-4.

1990 The Red River Coushatta Indian Villages of Northwest Louisiana 1790-1835. Louisiana Archaeology 12:129-178. 
Miller, Christina E. and Susan E. Wood

2000 Oakland Plantation, A Comprehensive Subsurface Investigation. Southeast Archeological Center, National Park Service, Tallahassee.

Moore, Clarence B.

1909 Antiquities of the Ouachita Valley. Journal of the Academy of Natural Sciences of Philadelphia, Volume 14, pp. 7-170, Philadelphia.

Morgan, David W.

2005 Phase II Archaeological Investigations at the American Cemetery (16NA67), Natchiloches Parish, Louisiana. The Cultural Resources Office, Northwestern State University of Louisiana, Natchitoches.

Walker, Winslow

1935 A Caddo Burial Site in Natchiloches, Louisiana. Smithsonian Miscellaneous Collections, Vol. 94, pt. 14. U.S. Government Printing Office, Washington, D.C.

Webb, Clarence H. and Hiram F. Gregory

1986 The Caddo Indians of Louisiana, Second Edition. Department of Culture, Recreation and Tourism, Louisiana Archaeological Survey and Antiquities Commission, Anthropological Study No. 2, Baton Rouge.

Webb, Clarence $\mathrm{H}$.

1945 A Second Historic Caddo Site at Natchitoches, Louisiana. Bulletin of the Texas Archaeological and Paleontological Society 16:52-83.

1963 The Smithport Landing Site: An Alto Focus Component in DeSoto Parish, Louisiana. Bulletin of the Texas Archeological Sociely 34:143-187.

n.d. Unpublished notes on file at Northwestern State University of Louisiana, Natchitoches.

Weinstein, Richard A., David B. Kelley, and Joe W. Saunders

2003 Introduction. In The Louisiana and Arkansas Expeditions of ClarenceBloomfield Moore, edited by R. A. Weinstein, D. B. Kelley, and J. W. Saunders, pp. 1-213. The University of Alabama Press, Tuscaloosa. 